\title{
EFFECT OF RECOMBINANT ERYTHROPOIETIN ON PERIPHERAL T LYMPHOCYTES
}

Kouichi Hisatomi, MD, ${ }^{a}$ Masanobu Nakao, MD, ${ }^{\mathrm{b}}$ Tadashi Isomura, MD, ${ }^{\mathrm{a}}$ Kenichi Kosuga, MD,

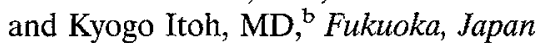

Recombinant erythropoietin ${ }^{1}$ has commonly been used to reduce the volume of homologous blood transfusion in patients undergoing cardiac opera-tions in Japan. $\mathrm{We}^{2}$ have reported that recombinant erythropoietin treatment not only increased levels of circulating erythrocytes but also improved indices of cell-mediated immunity, and $\mathrm{we}^{3}$ have suggested that it might help to ameliorate or prevent the impairment of immune function that can occur after cardiac operations. We subsequently administered recombinant erythropoietin in a dosage of $200 \mathrm{U} / \mathrm{kg}$ per day for 7 days in a patient with postoperative erythroderma associated with pancytopenia after a cardiac operation. The level of interleukin-2 production was also found to increase in association with lessening of symptoms. In the present study, we investigated the effect of recombinant erythropoietin on peripheral $\mathrm{T}$ cell response with the use of a reverse-transcriptase polymerase chain reaction (PCR), which has currently been acknowledged to detect cytokines in vitro in immunologic studies. Peripheral blood mononuclear cells were obtained 7 days postoperatively from 10 patients who underwent valvular operations. Five of the patients without complications were given recombinant erythropoietin in a dosage of $100 \mathrm{U} / \mathrm{kg}$ for 7 days, and the other five patients were not. Samples were prepared by the Ficoll-Conray method. They were adjusted to a concentration of $4 \times 10^{6}$ cells per milliliter and were incubated with 5 , 10,50 , or $100 \mathrm{U} / \mathrm{ml}$ of recombinant erythropoietin for 6 hours at $37^{\circ} \mathrm{C}$. Ribonucleic acid (RNA) was isolated by the RNAzol method (Biotecx Laboratories, Inc., Houston, Tex.). Cyclic deoxyribonucleic acid was prepared essentially as described by Becker, Quay, and Soukup. ${ }^{4}$ The PCR primers used for this study were interleukin-2 primers

From the Second Department of Surgery a and the Department of Immunology, ${ }^{\mathrm{b}}$ Kurume University School of Medicine, Fukuoka, Japan.

J ThORAC CARDIOvasc SURG 1995;109:809

Copyright $(\mathcal{C} 1995$ by Mosby-Year Book, Inc. $0022-5223 / 95 \$ 3.00+0 \quad \mathbf{1 2 / 8 / 5 7 7 8 1}$ (sense primer: 5'-TGTACAGGATGCAACTCCTGTCTT; antisense primer: 5'-GTTAGTGTTGAGATGATGCTTTGAC). PCR was performed for 35 cycles. Reversetranscriptase PCR-amplified messenger RNA was electrophoresed in a $1.5 \%$ agarose gel and stained with ethidium bromide. ${ }^{5} \mathrm{~T}$ cells separated from peripheral blood mononuclear cells mixed with 5 or $10 \mathrm{U} / \mathrm{ml}$ of recombinant erythropoietin did not express interleukin-2, whereas the samples mixed with 50 or $100 \mathrm{U} / \mathrm{ml}$ of recombinant erythropoietin had decreased expression regardless of whether patients received recombinant erythropoietin for 7 days after the operation. These findings suggest that, at the messenger RNA level, recombinant erythropoietin may inhibit production of interleukin- 2 from $\mathrm{T}$ cells in proportion to the dose. These results suggest that further study will be needed to reveal the true effect of recombinant erythropoietin on cell-mediated immune responses.

\section{REFERENCES}

1. Jacobs K, Shoemaker C, Rudersdorf R, et al. Isolation and characterization of genomic and cDNA clones of human erythropoietin. Nature 1985;313:806-10.

2. Hisatomi K, Isomura $T$, Kawara $T$, et al. Changes in lymphocyte subsets, mitogen responsiveness, and interleukin-2 production after cardiac operations. J THORAC CARdiovasc Surg 1989;98:580-91.

3. Hisatomi K, Isomura T, Galli SJ, Yasunaga $\mathrm{H}$, Hayashida $\mathrm{N}$, Ohishi K. Augmentation of interleukin-2 production after cardiac operations in patients treated with erythropoietin. J Thorac CARdiovasc Surg 1992;104:278-83.

4. Becker S, Quay J, Soukup J. Cytokine (tumor necrosis factor, IL-6 and IL8) production by respiratory syncytial virus-infected human alveolar macrophages. J Immunol 1991;147:4307-12.

5. Hoshino T, Yamada A, Honda J, et al. Tissue-specific distribution and age-dependent increase of human CD11b+ T cells. J Immunol 1993;151:2237-46. 